\title{
The Guardian of the Turkish Constitution: A Special Court
}

\author{
Peri Uran ${ }^{1} \&$ Pasquale Pasquino ${ }^{1}$ \\ ${ }^{1}$ Politics Department, New York University, United States \\ Correspondence: Peri Uran, Post doctoral Research Fellow at Politics Department, New York University, United \\ States.E-mail:pu271@nyu.edu
}

Received: March 4, 2015 Accepted: March 24, 2015 Online Published: May 27, 2015

doi:10.5539/jpl.v8n2p88 URL: http://dx.doi.org/10.5539/jpl.v8n2p88

\begin{abstract}
Court-based constitutional review as a way of controlling executive and legislative action is generally considered as one of the most significant developments in post Second World War liberal constitutionalism in the world. ${ }^{1}$ Constitutional courts can make a significant contribution to the preservation of the rule of law, the protection of the individual's fundamental rights and the strengthening of democracy as long as they remain independent. Constitutional courts are perceived as important factors of stabilization in many countries characterized by new or fragile democratic systems. ${ }^{2}$ Due to their potential role in the establishment and maintenance of constitutional democracies, constitutional courts have been comprehensively studied in the area of constitutional law and politics. ${ }^{3}$ In this study, the Turkish Constitutional Court, as one of the oldest and most active in Europe, will be examined in a comparative perspective by considering the interpretation of the historical origins and functions of the Constitutional Courts.
\end{abstract}

Keywords: constitutional democracy, constitutional review, Turkish Constitutional Court, Hirschl's 'hegemonic preservation' theory, juristocracy

\section{The Creation of the Turkish Constitutional Court: An Important Actor in Turkish Politics and Legal System}

In contrast to the decentralized "American model" of constitutional review, whereby all federal courts are empowered to set aside legislation if it violates the constitution and have the authority to adjudicate constitutional issues while resolving legal controversies, the so called "centralized European model" gives the authority of striking down or interpreting and modifying statutory law to a specialized quasi-monopolist ${ }^{4}$ court. $^{\text {. }}$ The "European model" of constitutional review has its origins in the constitutions of Austria and Czechoslovakia both of which were proclaimed in 1920. Under the influence of Hans Kelsen, these constitutions introduced into the Old Continent a specialized organ with the authority to determine the hierarchy of legal norms. After the World War II (1939-1945), as envisaged by the new constitutions and based on the "centralized European model", new constitutional courts were established in several regions of the world, including Latin America, Asia and Africa in addition to Europe. ${ }^{5}$

\footnotetext{
${ }^{1}$ McWhinney, E. W. (2002). Supreme Courts and Judicial Law-Making: Constitutional Tribunals and Constitutional Review. Boston: Kluwer Academic Publishers. p. 1.

${ }^{2}$ Schwartz points out that constitutional courts emerge during the building of democratic regimes, after experiences of authoritarian regimes "in which constitutional norms and guarantees had been violated or disregarded, often with the collaboration of the legislature". See, Schwartz, H. (2000). The Struggle For Constitutional Justice in Post- Communist Europe. Chicago: Chicago University Press, p. 19.

${ }^{3}$ Concerning East Asia see, Ginsburg, T. (2003). Judicial Review in New Democracies: Constitutional Courts in Asia. Chicago: Chicago University Press; and also concerning specific countries: Boyle, K \& Sherif A. O. (1996). The Road to the 1971 Constitution: A Brief Constitutional History of Modern Egypt. In K. Boyle \& A. O. Sherif (Eds.), Human Rights and Democracy: The Role of the Supreme Constitutional Court of Egypt. Boston, London and The Hague: Kluwer Law International; Moustafa, T. (2007). The Struggle For Constitutional Power: Law, Politics, and Economic Development in Egypt. New York: Cambridge University Press; Trochev, A. (2011). Judging Russia: The Role of The Constitutional Court in Russian Politics 1990-2006. New York: Cambridge University Press.

${ }^{4}$ We use this term since in a variety of national contexts ordinary judges are involved in different ways in the process of constitutional adjudication, either since they have the authority of sending questions to the Constitutional court, like in Italy or Germany, or because of their role of filtering the referrals like it is the case in France where notably since 2010 the Cassation Courts and the Council of State, the two highest jurisdictions, may prevent that a referral reaches the Constitutional Council. In reality the classical opposition between diffuse and centralized constitutional review is essentially obsolete.

${ }^{5}$ Ginsburg, T. (2003). Judicial Review in New Democracies: Constitutional Courts in Asia. Chicago: Chicago University Press, footnote 2.
} 
Turkey was one of the first countries in Europe that have adopted a centralized system of the judicial review to check the constitutionality of laws. The Turkish Constitutional Court was established by the Constitution of 1961 which was drafted after the 1960 Coup d'Etat ${ }^{6}$. To explain why the Turkish state established a constitutional court, one must first overview Turkey's constitutional history.

In the Ottoman-Turkish history the first constitution was proclaimed in 1876. The 1876 Constitution, the first modern constitution outside Europe and the Americas, proclaimed fundamental rights and freedoms of the Ottoman subjects, and led to the establishment of several institutions, such as a bicameral legislature (Meclis- $i$ Umumi) and a dual executive structure, consisting of the Sultan and the 'Council of Ministers' (Heyet-i Vükela). However, the constitutionalist movement in the Empire began long before the promulgation of the Constitution of 1876. The Sultan formally recognized for the first time the fundamental rights and freedoms of his subjects including security of life, honor and property, the equality of all Ottoman subjects irrespective of religion, the abolition of tax farming, fair and public trial of people particularly those of non-Muslims in the "Rescript of Tanzimat" of $1839^{7}$ and the "Rescript of Islahat (Reform)" of $1856^{8}$. Although an effective legal mechanism was not established to ensure the enforcement of these provisions, which remained only morally binding upon the Sultan, these reform rescripts had a momentous role in the constitutional development of the Ottoman Empire. The Ottoman Constitution of 1876 was substantially amended to increase the powers of legislature and to restrict those of the Sultan in 1909. Thus, the constitutional system eventually became similar to the parliamentary monarchies of Western Europe. ${ }^{9}$

Parliamentarism has been one of the foundational aspects of the Turkish constitutional and political system. Based upon the principle of the "supremacy of parliament", The Constitution of 1921 established an "assembly government". 1921 Constitution of Turkey's National Independence War was more of a document addressing the crucial political problems of the moment than a thorough constitution in a modern sense. The Constitution of 1924, which was a product of the military-bureaucratic elites ${ }^{10}$, came into effect after the promulgation of the Republic in 1923. This constitution was based on the majoritarian concept of democracy and resembled an assembly government with parliamentary overtones. ${ }^{11}$ The 1924 Constitution concentrated all powers in a unicameral legislature which was dominated by a single-party (Republican People's Party - RPP). It did not adopt the principle of constitutional review and did not offer effective guarantees for fundamental rights and liberties. The historical process leading to the emergence of a constitutional court can be summarized as:

" ...So long as legislative majorities are assured through single-party elections, the absence of constitutional review and of the independence of the judiciary gave the military-bureaucratic elites a great advantage to legislate and implement their political programs. But the coming to

\footnotetext{
${ }^{6}$ Metin Heper considers the military interventions as major obstacles that Turkish politics continually confronts. According to him, since the beginning of competitive politics in the mid-1940s, severe tensions between the government and the opposition have repeatedly jeopardized the legitimacy of civilian government and multiparty system. Indeed, government-opposition conflicts played a major role in sparking the three military interventions (of 1960, 1971, and 1980) that have punctuated Turkish political life since the Second World War; see, Heper, M. (1992). Consolidating Turkish Democracy. Journal of Democracy, 3 (2), p. 105.

Prof. Kili summarizes the reasons for the 1960 military intervention and asserts that: "Lack of experience with a multi-party regime, acute tension between the Democratic Party and the Opposition, increasing economic difficulties, violation of Atatürk's reforms, dictatorial measures of the DP government to silence criticism of its policies by the Opposition, and attempts of the DP government to involve the army on behalf of its policies led to the May 27, 1960 Revolution." See, Kili, S. (1992). Turkish Constitutional Developments: An Appraisal. Capital University Law Review, 21, p. 1974.

${ }^{7}$ S. Hanioğlu points out that up to 1839 , the Ottoman legal system recognized three major groups among the inhabitants of the empire: "Muslims, dhimmis (scriptuaries, or people of the Book, living under Muslim rule) and musta'mins (non-muslim foreigners residing in the empire). The shari'a applied to all issues involving Muslims. But when it came to the adjudication of internal matters, such as family law, non-Muslims had a choice: They could submit cases either to their own religious institutions or to shari'a courts. By and large, non-Muslims preferred the former course of action. Cases between individuals of the same foreign nationality were settled according to the law of their country of origin by special magistrates located within their embassies or consulates. Legal conflicts between a non-Muslim foreigner and a Muslim were settled in shari'a courts with the presence of dragoman (the translators in Ottoman Empire)." See, Hanioğlu, Ş. (2008). A Brief History of the Late Ottoman Empire. New Jersey: Princeton University Press, p. 19.

${ }^{8}$ The Rescript of Islahat is available at http://www.anayasa.gen.tr/reform.htm

${ }^{9}$ Özbudun, E. (2008). Türk Anayasa Hukuku (Turkish Constitutional Law). Ankara: Yetkin Press, p. 28-29.

${ }^{10}$ Şerif Mardin considers the confrontation between center and periphery as the most important social and cleavage underlying Turkish politics. See, Mardin, Ş (1973). Center-periphery Relations: A Key to Turkish Politics. Daedalus, 102(1), p. 170.

Here, what is meant by the center is central military and the bureaucratic elites and by the periphery is all social forces that are not belong to the military-bureaucratic ruling class.

${ }^{11}$ Regarding the parliamentary overtones, see Article 7, Article 44 and Article 46 of the Constitution of 1924, available in Earle, E. M. (1925). The New Constitution of Turkey. Political Science Quarterly, 40(1), p. 89, 94.
} 
power of the peripheral forces (Democratic Party-Demokrat Parti) with the 1950 elections changed the situation radically ${ }^{12}$. Starting from 1950, the RPP, as the representative of the military-bureaucratic elites, strongly insisted on the adoption of constitutional review and the independence of the judiciary. The demand for the establishment of a constitutional court was expressed in the 1957 election platform of the RPP and its Declaration of First Objectives issued on 14 January 1959. However, this time the DP, itself enjoying the advantages of majoritarian democracy, did not look at such demands favorably. The two private member's bills presented to Parliament in the 1950s that proposed to grant review powers to general courts were not even debated in Parliament. In fact, in the 1950s, particularly in the 1957-60 period, many laws with very dubious constitutionality were passed, and this was one of the factors that prepared the political climate for the 27 May 1960 military intervention. The 1960-1961 Constituent Assembly ${ }^{13}$, strongly dominated by the state elites and its representative RPP, adopted constitutional review $^{14}$ without much debate, and the Constitutional Court became operative in 1962."15

The court's creation was a response to a prevalent perception among the military and bureaucratic elite that the Democratic Party, which controlled a parliamentary majority between 1950 and 1960, had abused power to eliminate political opposition and restricted fundamental freedoms, so the Turkish Constitutional Court was conceived of as an effective check over the arbitrary power of parliamentary majorities. The 1961 Constitution marked the military bureaucratic elite's distrust toward elected assemblies; and, concomitantly, this constitution

\footnotetext{
${ }^{12}$ Until 1950, Turkey was ruled without interruption for 24 years by Republican People's Party (RPP) with a single party system. RPP was established by Turkey's founding elite and the official ideology of this political party was the Kemalist ideology emphasizing modernization,
} nationalism and secularism.

After the 1950 elections, Democratic Party-DP (the so called "peripheral" forces) had come to power. Adam Przeworski defines a democratic political system in the following way: "The miracle of democracy is that conflicting political forces obey the results of voting. Incumbents risk their control of governmental offices by holding elections. Losers wait for their chance to win office. Conflicts are regulated, processed according to rules, and thus limited. This is not consensus, yet not mayhem either. Just limited conflict; conflict without violence.", See, Przeworski, A. (2005). Democracy as an Equilibrium. Public Choice, 123, p. 270. By considering Przeworski's definition, it can be asserted that a political system is democratic if the incumbent accepts to lose the election. Depending upon this evaluation one can argue that the RPP and the Kemalist ideology was not fully authoritarian since at least for a while they accepted losing the election in 1950.

${ }^{13}$ The Constituent Assembly prepared the Constitution of 1961 which established a classical parliamentary system and has been regarded as the most liberal in Turkish Constitutional history.

${ }^{14}$ Cases may come before Constitutional Courts in different ways, such as referral by lower courts (concrete control of norms), or from other branches of government (abstract control of norms), or through individual complaints (constitutional complaints) brought by citizens. See, Harding, A. , Leyland, P. \& Groppi, T (2009). Constitutional Courts: Forms, Functions and Practice in Comparative Perspective. In A. Harding \& P. Leyland (Eds.), Constitutional Courts: A Comparative Study. London : Wildy, Simmonds and Hill, p. 9.

Access to Turkish Constitutional Court can be made by three mechanisms. The article 152 of the Turkish Constitution of 1982 designates concrete control of norms, the article 150 of the Constitution designates abstract control of norms and the article 148 of the Constitution designates constitutional complaint mechanism which was introduced by the 2010 constitutional amendment. The Court of Cassation and Council of State were concerned about the fact that introducing the mechanism of constitutional complaint would bestow upon the Turkish Constitutional Court the authority as the super appellate court over the others. This concern has been considered and the constitutional court's review is limited with evaluating questions of unconstitutionality. According to the so called article, in the individual applications, no examination shall be made in areas that have to be evaluated in regular judicial appeals.

15 Özbudun, E. (2006). Political Origins of the Turkish Constitutional Court and the Problem of Democratic Legitimacy. European Public Law, 12(2), p. 217.

Right after May 27, 1960 military intervention, the Milli Birlik Komitesi (National Unity Committee) appointed a commission consisting of eminent scholars in the fields of constitutional and administrative law and political science, such as Prof. Dr. İlhan Arsel, Prof. Dr. Ragip Sarıca, Prof. Dr. Bahri Savcı, Prof. Dr. Hıfzı Veldet Velidedeoğlu ve Doç. Dr. Lütfi Duran, to draft a constitution. The majority of the members were affiliated with Istanbul University therefore the commission is referred to as İstanbul Commission. In the following days, the Faculty of Political Science, Ankara consisting of Prof. Dr. Tahsin Bekir Balta, Prof. Dr. Yavuz Abadan, Prof. Dr. Bahri Savc1, Dr. Necat Erder ve Dr. Bülent Daver constituted a science commission and prepared also a draft constitution by their own initiative. Both commissions recommended creating a constitutional court, which will function to prevent the government from using its majority to become despotic. According to the Article 173 of the İstanbul Commission Draft, the major function of the court was to control the conformity of laws, standing orders of the legislative organs and all type of decisions made by them to the Constitution. The same function was described as "to examine complaints that the laws or decisions of the Assemblies were contrary to the Constitution" in the Faculty of Political Science, Ankara Draft. The İstanbul Commission that envisaged more initiative by the Court formed the basis of the final version of the Constitution. See, Soysal, M. (1974). 100 Soruda Anayasanın Anlamı (The Meaning of Constitution in 100 Questions). İstanbul: Gerçek Yayınevi, p. 65-67; Onar, E. (2003). Kanunların Anayasaya Uygunluğunun Siyasal ve Yargısal Denetimi ve Yargısal Denetim Alanında Ülkemizde Öncüler (The Political and Judicial Review of The Constitutionality of Laws and The Precursors of Judicial Review in Our Country). Ankara: AÜHF Yayınları, p. 31; Tanör, B. (1996). Osmanll- Türk Anayasal Gelişmeleri (1789-1980) [Ottoman- Turkish Constitutional Developments (1789-1980)]. İstanbul: Afa Yayınları, p. 282-283; Öztürk, K. (1966). Türkiye Cumhuriyeti Anayasası (Turkish Republic Constitution). Ankara: Türkiye İş Bankası Kültür Yayınları, p. 23-338. 
produced a system of checks and balances to limit the power of elected assemblies. Accordingly, the new constitution introduced the system of judicial review to ensure the constitutionality of laws, established a second chamber of the legislative assembly, and strengthened the administrative courts and the independence of the judiciary. In addition, it provided the universities, Radio and Television Corporation (TRT) with administrative autonomy. ${ }^{16}$ Consequently, the political sovereignty was shared by the elected and non elected agencies.

\section{The Activism of the Court}

According to Professor Ergun Özbudun, a specialist on Turkish Constitutional Law, the choice of constitutional review in Turkey, one of the earliest and allegedly most effective in Europe, can be explained in terms of Ran Hirschl's "hegemonic preservation" thesis:

".... In Hirschl's view, the fundamental reason of adopting judicial review is not a suddenly appeared idealist thought to provide a better protection of human rights, but the desire of once dominant and now threatened political elites to protect their status by means of constitutional guarantees. Those political elites that perceive their declining electoral support and do not wish to submit their fundamental values and interests to the uncertainties of the mechanisms of majoritarian democracy, have preferred to leave the protection of such interests to an independent judiciary whom they hoped to influence more easily. ${ }^{17}$ It can be argued that in practice of the 1982 Constitution the Constitutional Court has behaved essentially in the direction of the expectations of the state elites that created and empowered it. This attitude can most clearly be observed in the party prohibition cases. The Constitutional Court has consistently closed down Islamist and ethnic Kurdish political parties through a rigid interpretation of the Constitution and the Political Parties Law. ${ }^{18}$ Thus, it has given absolute priority to protecting the national and unitary state, and the principle of secularism, the two basic pillars of the Kemalist system of thought." ${ }^{19}$

As suggested by Özbudun, the Turkish Constitutional Court functioned in conformity with the expectations of Hirschl's "hegemonic preservation theory" as one of the chief representatives of the state elites. ${ }^{20}$ Indeed, the judiciary in general, and the Turkish Constitutional Court in particular has been conceived of as the ultimate stronghold of the secularist and nationalist ideology of Turkish Republic.

The Turkish Constitutional Court, which is considered as the most activist Court in Europe, ${ }^{21}$ to date dissolved

\footnotetext{
${ }^{16}$ In the Introduction of the official website of Turkish Constitutional Court, the task of the Court is stated as : '....to ensure that all institutions of the state abide by the Constitution. Since its foundation in 1962, the Court has helped to secure respect for and effectiveness of democracy, the rule of law and fundamental rights and freedoms. Consistently abiding by the Constitution, the Constitutional Court guarantees the irreversibility of the fundamental principles of the Turkish Republic.' Available at, http://www.anayasa.gov.tr/en/Introduction/

${ }^{17}$ As parallel to this evaluation, Ceren Belge incisively sums up the critical juncture of 1960-1961 in the following way: ".....Republican groups lost their privileged status with the DP's electoral victory after the transition to democracy in 1950. The Democratic Party's (DP) repressive policies toward (Republican) opposition groups provided the grounds for the military intervention of 1960. In the ensuing period, Republican groups wrote a new constitution that would minimize the future power of elected majorities through a rigorous system of checks and balances. Thus, although the adoption of the new constitution and the establishment of the Constitutional Court (CC) reflected a reaction to the authoritarian majoritarianism of the DP, these moves toward constitutional democracy and the rule of law were not neutral in terms of substantial political values. In other words, the CC was not established as an impartial referee of a contract between Republicans and Democrats, but as the guardian of a Republican constitution against Democrats." See, Belge, C. (2006). Friends of the Court: The Republican Alliance and Selective Activism of the Constitutional Court of Turkey. Law \& Society Review, 40(3), p. 664.

${ }^{18}$ As Shambayati points out, closed political parties, particularly those with Islamist and pro-Kurdish social bases, quickly reorganize and appear under a new banner to challenge the boundaries imposed by the state. See, Shambayati, H. (2008). Courts in Semi-Democratic/Authoritarian Regimes: The Judicialization of Turkish (and Iranian) Politics. In T. Ginsburg \& T. Moustafa (Eds.), Rule by Law: the Politics of Courts in Authoritarian Regimes. New York: Cambridge University Press, p. 298.

19 Özbudun, E. (2006). Political Origins of the Constitutional Review. In O. Ergül (Ed.), Democracy and Judiciary. Ankara: Union of Turkish Bar Associations, p.286.

${ }^{20}$ Heper points out that the state elite (military officers, judges, and high-level bureaucrats) consider themselves as the only true heirs of the Kemalist legacy and the legitimate guardians of the national interest against the particularistic interests represented by elected politicians, political parties, and the parliament, or what is otherwise known as the "political" elite. See, Heper, M. (1985). The State Tradition in Turkey. Beverley: Eothen Press.

${ }^{21}$ Algan, B. (2011). Dissolution of Political Parties By the Constitutional Court in Turkey: An Everlasting Conflict Between the Court and the Parliament. Ankara University School of Law Journal, 60(4), p. 810.
} 
twenty-eight political parties ${ }^{22}$. Some of the decisions of the Court were also brought before the European Court of Human Rights, and except the Wealth Party (Refah Partisi) case, the European Court found a breach of the Article 11 of the Convention in all cases. ${ }^{23}$

It would be illuminating to mention some of the party prohibition cases in order to understand the general tendency shown by the Court. Professor Zühtü Arslan, the current president of the Turkish Constitutional Court, examines the most controversial cases of the Court between 1990-2000 in an article and concludes that the cases in question demonstrate the court's bias in favor of ideology over rights. As regards one of these controversial cases, namely, that of United Communist Party of Turkey (TBKP), Arslan interprets the decision of the Court as follows:

"...16 July 1991, the Constitutional Court dissolved the United Communist Party of Turkey $(T B K P)$, ordering ipso jure the liquidation of the party and transfer of its assets to the Treasury. The founders and rulers of the party were banned from holding similar office in any political party. The court cited two grounds for the TBKP's dissolution. First, the party's incorporation of the word 'communist' into its name was found to be contrary to Article 96 (3) of the Political Parties Act. That article states: "No political party shall be formed with the name "communist", "anarchist", "fascist", "theocratic" or "national socialist" the name of a religion, language, race, sect or religion, or a name including any of the above words or similar ones.' Second, statements in the TBKP's constitution about the "Kurdish question" were construed as encouraging separatism and the division of the Turkish nation, both of which are prohibited by the Constitution (Articles 2.3, 66, and 68) and the Political Parties Act (Articles 78, 80, 81)..."24

Another striking example that indicates the Court's understanding of secularism is the Wealth Party (Refah Partisi) Case. Arslan summarizes the court's justification for dissolving Wealth Party as follows:

"On 16 January 1998 the court, basing its decision mainly on speeches made by party leader Necmettin Erbakan and some other officials, dissolved the Wealth Party (Refah Partisi) on the grounds that the party had become the 'center' of activities against the principle of secularism... For the Constitutional Court, 'secularism is based on national sovereignty, democracy, freedom and science, and as such is the contemporary regulator of the political, social and cultural life.' The court also emphasized that the application of the principle of secularism may be different in Turkey from its application in Western countries. By referring to this 'Turkish type of secularism,' the Constitutional Court appeared to justify its judgment that speeches and activities of Erbakan and some other party members contravened the principle of secularism." 25

The perception of the Court being the ultimate stronghold of the secularist and nationalist ideology of Turkish

Parliamentary Assembly, Council of Europe (PACE), in its Written Declaration No. 409 of 18 April 2008 (Doc. No: 1159), states that "Turkey has a legacy of political party closures almost all of which have resulted in findings of violations of Article 11 of the European Convention of Human Rights". Judicial proceedings against the Justice and Development Party in Turkey, available at

http://www.assembly.coe.int/ASP/Doc/XrefViewHTML.asp?FileID=12122\&Language=EN

${ }^{22}$ Legal grounds for dissolution of political parties by the Constitutional Court can be found both in the Constitution and the Law on Political Parties. After two major amendments in 1995 and 2001, articles 68 and 69 of the Constitution set up rules on this subject and accordingly, a political party can face dissolution as a result of violating the constitutional prohibitions by its statute and program; its activities; and receiving financial aid from foreign states, international institutions, persons and corporate bodies. The permanent dissolution of a political party shall be decided when it is established that its statute and program violate the provisions of Article 68, paragraph 4 of the Constitution. Paragraph 4 of the article indicates that the statutes and programs, as well as activities of the political parties cannot be in conflict with the independence of the State; its indivisible integrity with its territory and nation; human rights; the principles of equality and rule of law sovereignty of the nation; the principles of the democratic and secular republic. Another constitutional reason for the closure of a political party is to accept financial aid from foreign states, international institutions and persons and corporate bodies, as indicated in Article 69, paragraph 10 of the Constitution.

${ }^{23}$ See the Case of United Communist Party of Turkey and Others v. Turkey, Judgment of 30.1.1998; Case of the Socialist Party and Others v. Turkey, Judgment of 25.5.1998; Case of Freedom and Democracy Party (ÖZDEP) v. Turkey, Judgment of 9. 12. 1999; Case of Yazar, Karatas,, Aksoy and the People's Labour Party (HEP) v. Turkey, Judgment of 9. 4. 2002.

${ }^{24}$ Arslan, Z. (2002). Conflicting Paradigms: Political Rights in the Turkish Constitutional Court. Critique: Critical Middle Eastern Studies, 11, p. $15-16$.

25 Ibid. 
Republic grew rapidly after the Justice and Development Party (JDP) which had Islamist roots came into power in November $2002 .^{26}$

\section{Consecutive Clashes between Government and the Constitutional Court}

The activism of the constitutional court entered into consecutive clashes between JDP government and the Court. Such a clash of ideas between the constitutional court and the legislature induced a political crisis in Turkey over the election of the President of the Republic in 2007. The ruling of the Court concerning the quorum for election deadlocked the election process and resulted in a constitutional amendment. According to this amendment, the president would henceforth be elected by popular vote. The adoption of the principle of popular election of the president has changed the governmental system literally from parliamentary to parliamentary with president system. To emphasize, it was the political conflict between the ruling political party and the constitutional court over the question of presidential election that paved the way for this constitutional amendment. ${ }^{27}$

In 2008, the tension between the judiciary and the government regenerated when the Chief Public Prosecutor of the Court of Cassation (Yargıtay), Abdurrahman Yalçınkaya, prepared an indictment for the attention of the Constitutional Court, which claimed the dissolution of Justice and Development Party and banning its leading members from further involving in politics. According to this indictment:

"It is a fact that the Justice and Development Party (JDP) will use material power to change the secular order because it enjoys the government power today and this danger is not far. This is a fact when we consider that they will adopt Shariah by enabling the society to evolve towards an Islamic structure through what they call consensus processes. The JDP would use jihad as required by Shariah and if it fails to achieve to establish the regime it aims. In other words, the use of jihad, i.e. violence is probable. The threat posed by the policies of the JDP is clear and present. Concrete steps have been taken that may harm the civilized peace and the democratic regime in the country. In this context, there is no other possibility than closing the party as the only sanction applicable and also required by the society in order to protect the society from this danger and to prevent JDP from reaching its objective." 28

Among the eleven members of the Constitutional Court, six judges voted for the dissolution of JDP and four judges voted for the sanction of deprivation of JDP from the financial aid. Only one judge was of the opinion that the actions of the Party did not involve any sanction. In other words, except for only one associate judge, all other judges requested that a sanction be applied to the JDP. Nevertheless, according to the constitutional amendment of 2001, which made it more difficult to issue a court verdict to dissolve a political party (it has required seven out of eleven votes), Justice and Development Party has maintained its existence in the political life.

On September 12, 2010, in a dramatic coincidence with the 13th anniversary of the 1980 military coup, the Turkish electorate approved a JDP-proposed constitutional amendment package that drastically changed the structure of the Turkish Constitutional Court, in particular and the judiciary, in general. ${ }^{29}$ The changes in the

\footnotetext{
${ }^{26}$ Democratic Society Party was the recently banned political party by the Turkish Constitutional Court in 2009. The rationale of the Court was that Democratic Society Party had become the center of activities aiming to destroy the unity of the state with its territory and nation and to support $P K K$, considered a terrorist organization. According to the Constitutional Court, the relationship between Democratic Society Party and the terrorist organization $P K K$ was a "manifest secret" that Party had abstained from defining the $P K K$ as a terrorist organization. See, http://www.anayasa.gov.tr/index.php?l=manage_karar\&ref=show\&action=karar\&id=2756\&content=

The Constitutional Court concluded that the findings and conclusion of the ECHR in the Case of Herri Batasuna \& Batasuna v. Spain was applicable to the Democratic Society Party case in its entirety, and held that dissolution of the defendant party was necessary in a democratic society. See, Algan, B. (2011). Dissolution of Political Parties By the Constitutional Court in Turkey: An Everlasting Conflict Between the Court and the Parliament. Ankara University School of Law Journal, 60(4), p. 830.

${ }^{27}$ In order to understand the backdrop of the political conflict between the majority and the Constitutional Court concerning the election of the president, please see, Uran, P. (2010). Turkey's Hasty Constitutional Amendment Devoid of Rational Basis: From a Political Crisis to a Governmental System Change. Journal of Politics \& Law 3(1), p. 2-3.

${ }^{28}$ The Functioning of Democratic Institutions in Turkey: Recent Developments, Parliamentary Assembly, Council of Europe (PACE), 24 June 2008 (Doc. No: 1166) available at, http://www.assembly.coe.int/ASP/Doc/XrefViewHTML.asp?FileID=12122\&Language=EN

${ }^{29}$ Raising of the decisional quorum of the Court from three-fifths to two-thirds majority in party prohibition cases and introducing the procedure for constitutional complaint for individuals are other consequential changes. Besides these, restriction the area of competence of military courts in favor of civilian courts, introduction of new fundamental rights as children's rights, the introduction of an Ombudsman took part in the amendment package as well. The package was strongly supported by the EU members and the Venice Commission of the Council of Europe as an important step towards democratization. It is too early to produce an assessment of the consequences of these measures, notably concerning the constitutional complaints, which seem based on the German model.
} 
composition of the Court introduced by the 2010 constitutional amendment which has been conceived of as a response by political elites, can be regarded as a significant victory for the JDP government. ${ }^{30}$

According to the former article 146 of the Constitution of 1982, the Constitutional Court must be composed of 11 regular and 4 substitute members. It requires that a majority of the members must be appointed by the President of the Republic from among the candidates nominated by the Court of Cassation (2 regular, 2 substitutes), the Council of State ( 2 regular 1 substitute), the Military Court of Cassation (1 regular), the Supreme Military Administrative Court (1 regular), the Court of Accounts (1 regular), the Council of Higher Education (1 regular) from among their own members. Three regular members and one substitute member must be appointed directly by the President from among senior administrative officers and practicing lawyers. According to the amended article 146, the Constitutional Court must be composed of 17 members. Three of its members must be elected by the Turkish Grand National Assembly (TGNA) from among candidates nominated by the Court of Accounts ( 2 members), and presidents of the bar associations ( 1 member). The amended article stipulates that the three members elected by TGNA must acquire a two-thirds majority of the Assembly's full membership. If this majority cannot be reached in the first round, in the second round an absolute majority must be reached, and if such a majority cannot be reached on the third round, a simple majority would be sufficient. It must be emphasized that a qualified majority was preferable to ensure a more credible impartiality of the Constitutional Court judges.

The novelty introduced by the 2010 constitutional amendment essentially involves a limited role for parliament in the selection of judges, but such a change can still be considered as a contribution to strengthening the democratic legitimacy of the Constitutional Court ${ }^{31}$. To remember, only a one-third of the members of the Constitutional Court had been elected by the TGNA according to the 1961 Constitution.

The amended article provides the President of the Republic with a key role in the appointment of the remaining 14 members of Constitutional Court. According to the article, the President must exercise this power indirectly in the appointment of 10 members among the candidates nominated by the Court of Cassation ( 3 members), the Council of State (2 members), the Military Court of Cassation (1 member), the Supreme Military Administrative Court (1 member), and the Council of Higher Education ( 3 members). Four members must be directly appointed by the President among senior administrative officers, lawyers, senior judges and public prosecutors, and rapporteurs of the Constitutional Court. The former provision of the Constitution authorized the President to appoint only three regular members and one substitute member on his own discretion. Hence, the amendment does not increase the number of members to be directly elected by the President, but adds the reporting judges of the Constitutional Court and all judges and public prosecutors of the first degree to this category. Considering the former group's experience in constitutional justice, this may positively affect the quality of the Constitutional Court decisions. The members of the Constitutional Court shall serve for 12 years and a member shall not be re-elected.

The amendment package also revised the competence and function of the Constitutional Court as Supreme Court. According to the new provision, the Constitutional Court, when functioning as the Supreme Court, has the power to try high ranking officials, including the President, members of the Council of Ministers, and high courts' judges and prosecutors. According to the proposal, the Speaker of the Turkish Grand National Assembly and the Chief of Staff, the Commanders of the Land, Naval and Air Forces and the Commander of the Gendarmerie must also be tried by the Constitutional Court while functioning as the Supreme Court.

The provisions that has changed the constituency of the Constitutional Court and the High Council of Judges and Prosecutors (HSYK) attracted a furious reaction from the groups opposed to the constitutional amendment package on the grounds that the aforementioned institutions' composition would put the independence of the judiciary in danger and lead to a control of the judiciary by the ruling party, JDP.

The 2010 amendment package was considered as the first step toward a radically new and much more liberal constitution; and meanwhile the National Assembly has been designing a constitution that would not cause, but

\footnotetext{
${ }^{30}$ The current 1982 Constitution of Turkey has been amended seventeen times and ten of these amendments were implemented under the rule of the Justice and Development Party (JDP).

${ }^{31}$ As Bruneck points out, in most democracies, elected officials play a prominent role in determining the composition of judicial bodies that determine the constitutionality of laws. This method not only increases the democratic legitimacy of the courts but also reduces the ideological gap between elected officials and constitutional justices. See Bruneck, A. V. (1988). Constitutional Review and Legislation in Western Democracies. In C. Landfried (Ed.), Constitutional Review and Legislation: An International Comparison. Baden-Baden: Nomos, p. 224. On the other hand, if the members of the constitutional court are chosen by a single party, which also controls the majority in the Parliament, the partiality of these members of the Courts seems more than likely.
} 
rather resolve crises and bring into existence a well-functioning political system. In order to make a participatory and legitimate constitution, the Constitutional Reconciliation Commission of the Turkish Grand National Assembly welcomes the contributions from wide segments of the society including non- governmental organizations, trade unions, economists and social scientists as well as constitutional law experts. It is likely that the constitution making process in Turkey would take a while as it is a long-running constitutional engineering issue to compromise on critical issues such as independence of judiciary, minority rights, the principles of the nation-state and nationalism and civil-military relations.

\section{Tentative Assessment}

The interpretation of the origins and functions of the Turkish Constitutional Court as suggested by Ergun Özbudun following Hirschl's thesis, to which we have referred earlier in this study, encourages one to make a set of significant suggestions from a comparative perspective. This will be the yardstick against which we will raise some suggestions for a possible assessment.

To begin with, while speaking of the historical origins of a constitutional court, one must avoid two common fallacies. The first, and probably the most well-known one, is often labeled as the 'functionalist' fallacy. ${ }^{32}$ Falling into this fallacy, one believes that the way an institution functions indicates the motivations lying behind the emergence of this institution. There is another fallacy that one can label as "originalist". Here, one assumes that an institution automatically follows the intentions of those who established it. However, the way an institution functions may well diverge from the intentions (if we are aware of them) that had motivated its founders. Hence it is much more reasonable to make a distinction between two questions; that of origins and that of successive working of an institution. For the purpose of this study, when one gets concerned with the case of the Constitutional Courts, it is reasonable to suggest that the Turkish Constitutional Court was established to protect the Kemalist constitution of 1961 and concomitantly the Kemalist elite. The same can be argued as regards the reform of the referral mechanism to the French Constitutional Council that Giscard D'Estaing promoted in France (the so called saisine parlementaire) ${ }^{33}$; and considerably as regards the introduction of a Constitutional Court in the Italian Constitution in $1947^{34}$. It is perfectly reasonable to argue that Giscard D'Estaing - contrary to what he declared many times later on - intended to protect the conservatives from a possible victory of the left in the French election - what happened in 1981 - by expecting that the members of the Constitutional Council, appointed by conservative political actors, would have at least limited, if not prevented, the political and economic consequences of that possibility. Indeed, the Council cancelled a part of the nationalization statute passed by the Socialist majority after the victory of Mitterrand. It is also somehow reasonable, though oversimplified, to suggest that in the post-World War II Italy, the Christian Democrats induced the Constituent Assembly to include in the constitution an organ that would be able to protect the constitutional agreement with the Social-Communists. This was because the Christian democrats were anxious about the possibility that the Social-Communists could win the majority in the legislative assemblies in the Spring 1948 elections - something that did not happen - and modify the terms of the compromise reached in the Constituent Assembly. ${ }^{35}$

Still, these reasonable hypotheses regarding the origin of these institutions (or their transformations produced by the political branches) do not tell us enough concerning their future performance. First of all, in any democratic regime (like France and later on Italy), the party holding the majority in the parliament can, by definition, fall into opposition. Thus, rotation in power must be anticipated and an organ protecting the political minority $\mathrm{X}$ at a given time should be able to protect the minority $\mathrm{Y}$ in future unless the appointments of the members of the Constitutional Courts are controlled monopolistically by a single segment of the political elite. However, the

\footnotetext{
${ }^{32}$ For a definition and a radical criticism of the functionalist explanations, please see Elster, J. (1982). The Case for Methodological Individualism. Journal of Theory and Society, 11(4), p.453-482; Elster, J. (1983). Explaining Technical Changes: A Case Study in The Philosophy of Science. Cambridge: Cambridge University Press.

${ }_{33}$ Pasquino, P. (2009). The New Constitutional Adjudication in France. The Reform of the Referral to the French Constitutional Council in Light of the Italian Model, Indian Journal of Constitutional Law, 3(1), p. 105-117. Also available at http://www.astrid-online.it/Dossier--R2/Studi--ric/Pasquino_New-Constitutional-adjudication-France.pdf

${ }^{34}$ Pasquino, P. (2006). L'origine du contrôle de constitutionnalité en Italie: Les débats de l'Assemblée constituante (1946-47), Rivista Trimestrale Di Diritto Pubblico, 1, p. 11.

${ }^{35}$ Pasquino mentions that if someone thinks he will win, then he doesn't want anybody checking what he does, but when he realizes that he will lose and that the winners can do what they want, he may start thinking that an insurance is needed against the winner. See, Pasquino, P. (2009). The debates of the Italian Constituent Assembly concerning the introduction of a Constitutional Court (1947-1948). In P. Pasquale \& F. Billi (Eds.), The Political Origins of the Constitutional Courts: Italy, Germany, France, Poland, Canada and United Kingdom. Rome: Fondazione Adriano Olivetti, p. 111.
} 
segment of the political class that established the Constitutional Court would vie for being able to control systematically the composition and activities of the Court. Nevertheless, rotation in power naturally brings into being constitutional courts with members of different ideological leanings.

We are not claiming that there is a univocal causality between competitive elections and rotation in power, on the one hand, and the existence of a Constitutional Court that is able to exercise a de facto counter-power vis-à-vis the majority, on the other. There are significant examples of the exactly opposite. Although, the UK has a very old tradition of competitive elections it never introduced a Constitutional Court with the power to nullify statutory legislation. Italy developed a pretty effective Court notwithstanding the very long lasting governmental power of the Christian Democratic Party. We rather suggest that the existence or the anticipation of changing hands of power may induce the political actors to accept the existence of an organ limiting their power once in government, and that the original motivation for establishing such an institution may produce different effects, if rotation in power becomes a standard occurrence. An institution created to tie up the hands of B in the interest of A may be able to limit the power of A once A and B replace each other - which is what happens in proper and stable democratic regimes.

Our research focuses on the Turkish case. To begin with, the Kemalist elite at the outset - in 1961, when the Constitutional Court was introduced - not only took control of the political power, but it was able to protect that hegemonic position notably thanks to the army, which remained faithful to the secular authoritarian ideology. 1961 Turkish Constitution, similar to all the republican constitutions of the post-Ottoman Turkey, was produced in an authoritarian manner; it was, a positive Verfassung if one resorts to Carl Schmitt's conceptualization ${ }^{36}$, but it was imposed on the country by a section of its elite - notwithstanding the fact that the constitution was approved through popular referendum by $61.7 \%$ of the voters. Unlike the Italian or the German constitutions after Second World War, the 1961 Turkish Constitution was not based on an organization of the political power in accordance with a compromise between all the major social and political groups of society. Hence, the 1961 Turkish Constitution was protected by the military, and from the 'legal' point of view, the Constitutional Court was the guardian of this authoritarian constitution. Nevertheless, the planned function of the Court to protect and defend the power of Kemalist elite and its ideology proved unsuccessful in the long run. In the last thirteen years, the Justice and Development Party won every single election. Concomitantly, the alleged juristocracy became no more able to protect the political power of the Kemalist elite and other secular groups that established the constitutional court. At this point, Hirschl's concept of juristocracy loses its explanatory value. Because:

1. The political elite in general is divided and, with the exception of political systems where there is no real electoral competition, the segment of political elite that is stronger in a given moment in time - notably when it can impose its constitution (and pack the Court)- becomes eventually unable to keep its hold over political power and consequently loses its hegemony. 2. In such an unstable situation of power relations, it is naive to believe that the segment of the political class, which holds political power, can permanently control a judicial body. The judiciary would have the tendency to establish its own independent legitimacy and to stop being a servant of the segment of the political class that produced it. Hence, Hirschl's thesis needs to be seriously revised. A constitutional court may initially be serving the segment of political class to which it owes its existence. Nevertheless, as a result of rotation of political power or, as in Italy, if it manages to gain de facto independence, it eventually becomes a mechanism being able to limit the governmental power of the incumbent. In other words, it becomes a means of political "moderation", a means to check the political power of elected majorities.

In a democratic system, there is alternation in power between the majority and the opposition. This can be described in the following way: in $\mathrm{t} 1$ : A-b; in $\mathrm{t} 2 \mathrm{a}-\mathrm{B}$ (the capital designing the majority). In $\mathrm{t} 1$ we may assume that A creates the Constitutional Court to protect itself from B when and if A will become a. With rotation in power, if the Constitutional Court is independent (not controlled by the majority), it will be potentially able to protect whatever political minority. So in 3 the Constitutional Court may and tends to become an independent political actor. This is the case in a democratic society, as an extension of competitive elections. ${ }^{37}$

Since the Second World War, Turkey represents a peculiar case of figure. The Republican People's Party (RPP)

\footnotetext{
${ }^{36}$ Schmitt, C. (2008). Constitutional Theory. Durham: Duke University Press, p. 75.

${ }^{37}$ As we already observed there is no mono-causal relations between a democratic society with alternation in power and the existence of a Constitutional/Supreme Court able to act as a counter-power. There is probably a correlation. But societies with a longstanding non-authoritarian regime have been mostly reluctant to introduce a mechanism of control over the freely elected majority. On the other side, countries without regular alternation in power, like Italy, have been able to establish an independent Constitutional Court long before the political decline of the party, which has been hegemonic for about 45 years. So the reasons of the emergence of a real counter-power exercised by a Constitutional Court need to be explored in more details. The legal culture of a country and the post-authoritarian nature of the regime establishing a control upon democratic institutions may play an important role.
} 
notwithstanding its authoritarianism, accepted to be defeated by the challenger, the Democratic Party in 1950 . Between 1950 and 1961 there was no constitutional court in Turkey, which could be able to protect the Kemalist hegemony. Hence, a military intervention was the single way to bring back the power of the Republican People's Party. After the restoration of the Kemalist ${ }^{38}$ power, the Turkish Constitutional Court worked pretty efficaciously as a guardian of the political order - notably disbanding repeatedly the political parties of religious inspiration following the letter of the constitution. However, again in 2002, the incumbent had to concede the election to the challenger, Justice and Development Party and the Turkish Constitutional Court slowly became unable (like the military, progressively dismantled in its ability to interfere with the political process) to protect its author. A new hegemonic power seems to be able to control the guardian of the constitution, which has been modified in order to be adjusted to the new configuration of political power. If juristocracy means independent power of the Court, it becomes apparent that the Turkish Constitutional Court has been unable to establish its kratein - its independent power. If, instead, juristocracy means, that the political class instrumentalizes the constitutional court to maintain its privileged position, this thesis proves to be wrong in most democratic regimes. This is because a constitutional court ends up maintaining itself and its own power, not the power of the elected politicians. What seems specific to the Turkish political system is that the Constitutional Court is under the control not of the political power that created the Court but of the contemporary hegemonic power. The Turkish case shows that general oversimplified model to understand the role of constitutional courts in our societies are unpersuasive and tend to disregard the political reality. This is, in any event, the lesson we can learn by studying the Turkish political and constitutional history.

\section{Copyrights}

Copyright for this article is retained by the author(s), with first publication rights granted to the journal.

This is an open-access article distributed under the terms and conditions of the Creative Commons Attribution license (http://creativecommons.org/licenses/by/3.0/).

\footnotetext{
${ }^{38} \mathrm{We}$ are aware that speaking of Kemalism tout court is a big simplification. But we have no pretention to discuss here the details of the Turkish political life. Such an intellectual enterprise should distinguish between different variants of what we call Kemalism here.
} 